\title{
The Effect of Tourism Expansion on Firm Performance: Evidence from Japan
}

\author{
Bor-Yuh Lee
}

\section{ABSTRACT}

\begin{abstract}
This article examines whether an increase in tourism has a direct impact on tourism and tourism-related companies in Japan. Tourism expansion is theoretically assumed to have a direct influence on tourism companies, and previous studies have found the connection between tourism expansion and tourism companies. This chapter considers ROA and ROE as company performance indicators and the changes in the number of foreign tourists as the measurement of tourism expansion. The effects of tourism expansion on corporate performance are examined by a random effect in panel regression analysis. However, the results are not supported by current theories. The research shows that tourism expansion does not have a significant impact on the Japanese tourism industry. The empirical findings offer valuable information on the future of the tourism-based Country Promotion Basic Act for Japanese government policymakers, and experts in related industries.
\end{abstract}

Keywords: firm performance, tourism expansion.

\section{INTRODUCTION}

The relationship between operations and company performance has long been discussed [1], and the nature of the existence of the relationship has been proved [2]-[4]. Moreover, the significant causal relationship was built by Swamidass and Newell in 1987 [2]. Significantly, some analysis shows that circumstances solely determine company performance. Maintaining and improving market size becomes difficult for Japan, given its low birth rate. From 2007, Japan launched a series of national tourism promotion policies, and it views tourism as a pillar of its strategy. It has eased visa requirements and increased the number of low-cost carriers and other flights to boost international tourism. Also, the hosting of spectacular global hallmark events, such as the Olympics and Paralympics planned for 2020 in Tokyo, attracts millions of tourists. These events offer Japan a considerable number of business opportunities. This study offers peer-reviewed empirical evidence of the relationship between tourism expansion and the hotel industry's performance in Japan. First, we provide empirical evidence on whether tourism expansion can benefit hotels' firm performance. In our analysis, the relationship between tourism expansion and hotels' firm performance is not statistically significant. It is not identical with most of the previous research. Second, some particular reasons make Japan's situation unique. For instance, the industry in Japan suffers challenges from industrial innovations, and so on.

The remainder of this study is organized as follows. We present the literature review and hypotheses in the second section. We then examine the relationship between tourism expansion and firm performance. After introducing our research method, we perform a panel regression analysis to explore Japan's empirical data from 2008-2018. Finally, we present the conclusion and discussion of the outcomes, implications, and suggestions for further research.

\section{LITERATURE REVIEW}

Experts have argued about the meaning of the business environment for years. For instance, Okoh and Munene [6] point out that there are two perspectives of understanding the business environment. One is to consider the environment as a combination of general, social, technology, and economic conditions. Obasan [7] thinks the business environment is a full set of tangible and intangible related factors. Osuagwe [8] argues that we should consider the business environment as the totality of all the factors that affect the operations or business of a company. Moreover, Ogundele [9] claims the business environment determines and defines the opportunities, and it is crucial to a business: an expanding environment can provide growing space and increase its probability to survive.

The hospitality industry is considered a cyclical industry as it is highly sensitive to the state of the business environment [10], [11], and its fixed costs are higher than many other sectors. The primary fixed cost is the expenditure on real estate maintenance, which cannot be easily reduced unlike most other industries that can easily cut costs when their sales suddenly fall. Also, its fixed income is less than similar industries, such as asset management companies for real estate. Given the nature of the hospitality industry, its functioning is closely related to the business environment. Thus, the question, as pointed out by Graham and Harris, is 
how can hotels respond to the business environment to maintain the high revenues necessary for survival and make considerable profits?

According to previous studies, tourism expansion could improve economic conditions. Using Taiwan as an example, Kim et al. [12] proposed a hypothesis on the relationship between tourism expansion (measured by the total number of foreign visitors) and economic growth (measured by gross domestic product (GDP)). The analysis included a long-run equilibrium link and a bi-directional causality between the two indicators. Their study shows that the improved economy resulting from increasing numbers of foreign tourists could benefit the Taiwanese hotel industry by improving the business environment. Moreover, other researchers also found a similar phenomenon in African and European countries (e.g., Greece, Italy, and Spain). In summary, tourism development can significantly improve the business environment, which has an indirect effect on the corporate performance of hotel companies. Previous empirical studies show that tourism expansion can boost economic development [11], [13], [14].

To conclude, the growth in the number of tourists can increase revenues and earnings, which then improves the hotels' corporate performance. Accordingly, tourism expansion is expected to boost hotels' performance directly. Hence, we test the hypothesis in this study.

Hypothesis: Tourism expansion increases corporate hotel performance.

\section{METHOD}

\section{A. Samples}

In this study, we select the Japanese listed hotel companies as our research sample. The hotel industry is considered an industry that is sensitive to the state of the business environment [10], as the companies in the hotel industry always have much higher fixed costs than most other industries. Given its high fixed costs, hotels can neither easily cut costs to respond to falling income arising from a worsening business environment, nor can they increase the total number of rooms in boom times. Consequently, the corporate performance of hotels is synchronized with its business environment. The phenomenon of a hotel's performance accords with previous research [16]. In this study, the business environment will be measured by tourism expansion (the number of foreign tourists), as the number of foreign tourists has a direct effect on hotels' occupancy rates. This number is based on the requests for accommodation that will contribute to hotels' sales revenue. The firm performance data of the sample companies are selected from the Taiwan Economic Journal (TEJ) database from 2009-2018. The data on the total number of foreign tourists are drafted from the public data of the Japan National Tourism Organization published by the government of Japan.

\section{B. Variables}

Tourism expansion can boost occupancy rates and earnings to enhance the financial performance of hotel companies. Further, previous studies have shown that tourism expansion can promote economic development [16]-[18], and the improved economy caused by tourism expansion will eventually increase corporate income and profits. That is, a large number of tourist arrivals are considered to have a positive impact on hotels' firm performance. Accordingly, the firm performance of hotel companies is hypothesized to be positively related to the trends in tourist numbers.

\section{Measurement of Firm Performance}

Previous research shows that the definition of corporate performance is how well a company achieves its financial goals compared to the company's major competitors [1], [10]. In this study, we measure corporate performance by ROA and ROE.

\section{Other Control Variables}

1. Firm size is calculated as the natural log of total assets.

2. Disaster. According to Chen [11], massive disasters significantly affect the global business environment and people's intention of traveling; we take it as one of the control variables here. In this study, it denotes the dummy variable of the 2011 Tohoku earthquake and tsunami which caused the Fukushima Daiichi nuclear disaster, a Japanese national disaster. We accorded the variable tale, the value of 1 during the corresponding period on the event date, and 0 otherwise.

3. Firm Age is measured by the gap between the observation year and the company's founding year.

4. Number of Employees is measured by the total number of employee data from each company's annual report on the Tokyo Stock Exchange.

5. Debt Asset ratio is a financial ratio that indicates the percentage of a company's assets that are provided by debt.

6. Overseas is an instrumental variable measured by whether the company runs the hotel business out of Japan. The reason we take this as a variable is that international hotel groups have a better ability to attract foreign customers.

After summarizing all our research samples and data, our final sample consists of 12 companies and 107 firm-year observations covering all the information needed to test our hypotheses. Our hypotheses focus on exploring whether the tourism expansion benefits hotel companies' firm performance. Then, we conduct our analysis by using a panel regression model because it can control for both time effects and company effects. Following the guideline of model selection, we first take advantage of the F-test, then we use the Hausman test to choose the most suitable model in this study. However, the outcomes reveal that the most suitable one is the random effect panel regression.

\section{RESUlts}

\section{A. Descriptive Statistics}

The final sample in this study includes 107 observations from 145 firms over ten years from 2009-2018. We present the sample distribution by year and observe a percentage of the research sample in Table I. Table II shows the descriptive statistics and the outcome of the Pearson correlations for all our variables. Finally, in Table III, the full results of our panel regression analysis are displayed. 


\begin{tabular}{ccc}
\multicolumn{3}{c}{ TABLE I: SAMPLE DistRIBUTION } \\
\hline Sample by year & $\begin{array}{c}\text { No. of } \\
\text { observations }\end{array}$ & $\begin{array}{c}\text { Percentage of } \\
\text { sample }\end{array}$ \\
\hline 2018 & 9 & $8.41 \%$ \\
2017 & 11 & $10.28 \%$ \\
2016 & 11 & $10.28 \%$ \\
2015 & 11 & $10.28 \%$ \\
2014 & 11 & $10.28 \%$ \\
2013 & 11 & $10.28 \%$ \\
2012 & 10 & $9.35 \%$ \\
2011 & 11 & $10.28 \%$ \\
2010 & 11 & $10.28 \%$ \\
2009 & 11 & $10.28 \%$ \\
\hline Total & 107 & $100 \%$ \\
\hline
\end{tabular}

\section{B. Correlation Analysis}

Table II presents the descriptive statistics and correlations among all the variables. Overall, correlations among the independent variables are relatively modest. The correlations between the main independent variables are fair, which facilitates the separate identification of effects for these variables and their interactions. Besides, it is acceptable that some relationships exist between ROA, ROE, and total assets, as both formulas for ROA and ROE contain total assets. That they do not reveal a robust relationship with tourism expansion directly improves our standpoint for statistical inference. Also, we find that the relationship between firm age and some variables, such as staff numbers and company size is quite strong. The relationship between firm size and debt asset ratio and, so on, is fair.

\section{Regression Analysis Results}

Our empirical results for the panel regression are represented in Table III. In Model 1, the coefficient (Coef. = $1.986, \mathrm{p}>0.05$ ) of tourism expansion is positive to ROA (the indicator of firm performance, and the relationship keeps positive in our Model 2 (Coef. $=3.580, p>0.05)$. We cannot find significant evidence for the two models here. So, when we measure the relationship using ROA, there is no relationship between them here.

TABLE III: RESULTS OF RANDOM EFFECT PANEL REGRESSION ANALYSIS

\begin{tabular}{ccccc}
\hline & Model 1 & Model 2 & Model 3 & Model4 \\
\hline Intercept & 0.766 & $-1.248^{* *}$ & 0.811 & $-79.252^{* *}$ \\
Tourism & 1.986 & 3.580 & 4.439 & -3.721 \\
expansion & & & & \\
Control variables & & $1.952^{* *}$ & & $12.413 * *$ \\
Firm size & & 8.629 & & -0.008 \\
Firm age & & $-3.298^{* *}$ & & -17.515 \\
Debt asset ratio & & -1.661 & & -9.167 \\
Disaster & & 1.005 & & -0.001 \\
Number of staff & & -1.320 & & 3.253 \\
Branch overseas & & 0.165 & 0.003 & 0.120 \\
\hline $\mathrm{R}^{2}$ & 0.029 & 0.106 & -0.006 & 0.058 \\
Adj $\mathrm{R}^{2}$ & 0.020 & 19.571 & 0.33627 & 13.58 \\
$\mathrm{~F}$ & 3.187 & &
\end{tabular}

TABLE II: DESCRIPTIVE STATISTICS \& PEARSON CORRELATION

\begin{tabular}{ccccccccccccc}
\hline & Mean & Median & Min & Max & SD & 1 & 2 & 3 & 4 & 5 & 6 & 7 \\
1.ROA & 1.055 & 1.350 & -18.700 & 7.080 & 2.956 & 1.00 & & & & \\
2.ROE & 4.270 & 1.474 & -163.720 & 31.530 & 18.887 & 0.91 & 1.00 & & \\
3.TA & 0.24 & 0.165 & -0.2778 & 0.4715 & 0.224 & 0.15 & 0.05 & 1.00 & \\
4.Firm size & 7.788 & 7.741 & 6.694 & 8.880 & 0.515 & $\mathbf{0 . 3 2}$ & $\mathbf{0 . 2 8}$ & 0.01 & 1.00 & \\
5.Debt asset ratio & 0.724 & 0.674 & 0.026 & 0.944 & 0.192 & -0.16 & -0.11 & 0.01 & 0.17 & 1.00 & & \\
6.Firm age & 67.00 & 74.01 & 19.00 & 130.00 & 29.629 & -0.03 & 0.12 & $\mathbf{0 . 0 3}$ & -0.43 & -0.15 & 1.00 & \\
7.Staff & 443 & 1444 & 24 & 7592 & 1717.687 & $\mathbf{0 . 2 6}$ & $\mathbf{- 0 . 1 3}$ & $\mathbf{0 . 0 5}$ & 0.64 & -0.02 & $\mathbf{- 0 . 3 3}$ & 1.00 \\
\hline
\end{tabular}

1. In bold, the correlation is significant in $1 \%$ level.

2 . The value in $3 \& 4$ was transformed by taking the natural logarithm.
We explore the relationship between ROE and tourism expansion in Model 3 and Model 4, using the same approach. In Model 3, the coefficient (Coef. $=4.439, p>0.05$ ) of tourism expansion is positive for ROE (the indicator of firm performance. Also, the relationship in our Model 4 (Coef. = $3.421, p>0.05$ ) does not show their relationship significantly. So, we do not find any significant evidence for the two models here.

\section{CONCLUSION}

There is an existing concrete foundation with numerous studies on the relationship between tourism expansion and economic development. However, our understanding is on the effect of tourism expansion at industry level. Previous studies have suggested that tourism expansion directly affects corporate performance by boosting sales revenue and positively affecting firm performance by indirectly improving the business environment.

In this study, we reviewed previous research based on their theoretical framework. After controlling for several critical variables, we do not find that the hotels' company performance follows our expectations. Accordingly, we consider that the theory is insufficient to explain the empirical results. A possible reason is that a lot of firms engage in hotel industries as a part of their business segment portfolio due to the potential of this industry. However, most of the listed companies are public transportation companies, such as railways and airlines. A feature of these industries is the vast need for capital, for instance, a railway company needs land for daily operations and to build its railway systems. It also needs to make a railway network and purchase trains.

Our findings in this study offer empirical evidence of a counter-intuitive example of tourism expansion. The hotel industry does not benefit from an increase in tourists, which reminds us that we should perhaps pay attention to traditional competitive analyses of industry and business. In this study, the hotel industry does not have apparent entry barriers. On the contrary, the industry suffers from the sharing economy. For instance, Airbnb, a large platform for short-term accommodation, recently disrupted the hospitality industry. Zervas et al. [5] estimated the impact of Airbnb on the hotel industry in Texas. They studied the effect of Airbnb's entry on the Texas hotel industry and found that it reduced the hotels' income by about $8 \%-10 \%$. Our findings are an essential reference role for policymakers in government.

We propose limitations and suggestions to future researchers on the effect of tourism expansion, and Japan's tourism-based Country Promoters. Several limitations provide multiple directions for future research and discussion. 
First, concerning our research sample, the collection of hotels companies' data cannot represent all facets of the hospitality service industry, particularly some global startups, for example, Airbnb offers a lot of accommodation in Japan. Although it is not a hotel company, Airbnb offers its service to many tourists while simultaneously preying on the hotel companies' markets. Further, some famous large-scale enterprises in Japan, such as Mitsui Fudosan (real estate companies), Orix (financial service company), and Japan Railway Group (railway company), also operate their own hotels or hospitality facilities as a part of diversified business strategy. Consequently, it is one of our limitations in this study.

Second, it is difficult to determine the growth in the number of foreign visitors to Japan, and our figures include people from around the world. According to the World Bank, Japan's purchasing power parity in 2018 was ranked at 26, suggesting that the average tourist, from over one hundred countries, cannot meet the standard levels of consumption in Japan. Consequently, the growth in Japan's tourism market may be much smaller than expected.

\section{REFERENCES}

[1] W. Skinner, "Manufacturing-missing link in corporate strategy," 1969.

[2] P. M. Swamidass, W. T. Newell, "Manufacturing strategy, environmental uncertainty and performance: a path analytic model," Management science, vol. 33, no. 4, pp. 509-524, 1987.

[3] S. K. Vickery, C. Droge, R. E. Markland, "Production competence and business strategy: do they affect business performance?" Decision Sciences, vol. 24, no. 2, pp. 435-456.

[4] P. T. Ward, G. K. Leong, K. K. Boyer, "Manufacturing proactiveness and performance," Decision Sciences, vol. 25, no. 3, pp. 337-358, 1994

[5] G. Zervas, D. Proserpio, J. W. Byers, "The rise of the sharing economy: Estimating the impact of Airbnb on the hotel industry," Journal of marketing research, vol. 54, no. 5, pp. 687-705, 2017.

[6] P. E. Okoh, J. C. Munene, "The Organisation Dynamics, Environment Size, Managerial Values and Decision Choice", Nigeria, 1986.

[7] K. Obasan, "Small Business Management: An Entrepreneurial Approach", Higher Education Books Publishers, Lagos, 2001.

[8] L. Osuagwu, "Small business and entrepreneurship management," GreyResources Limited, Lagos, 2001.

[9] O. J. K. Ogundele, "Management and Organisation: Theory and Behaviour," Sabte Book Series, Lagos, Nigeria, 2005.

[10] Z. Bodie, A. Kane, A. J. Marcus, P. Mohanty, Investments (SIE). McGraw-Hill Education, 2008.

[11] M. H. Chen, "The economy, tourism growth and corporate performance in the Taiwanese hotel industry," Tourism Management, vol. 31 , no. 5 , pp. $665-675,2010$.

[12] H. J. Kim, M. H. Chen, "Tourism expansion and economic development: The case of Taiwan," Tourism management, vol. 27, no. 5, pp. 925-933, 2006.

[13] C. C. Lee, C. P. Chang, "Tourism development and economic growth: a closer look at panels," Tourism Management, vol. 29, no. 1, pp. 180 192, 2008.

[14] S. Proenca, E. Soukiazis, "Tourism as an economic growth factor: a case study for Southern European countries," Tourism Economics, vol 14, no. 4, pp. 791-806, 2008.

[15] I. C. Graham, P. J. Harris, "Development of a profit planning framework in an international hotel chain: a case study," International Journal of Contemporary Hospitality Management, vol. 11, no. 5, pp. 198-208, 1999.

[16] L. Gunduz, J. A. Hatemi, "Is the tourism-led growth hypothesis valid for Turkey?" Applied Economics Letters, vol. 12, no. 8, pp. 499-504, 2005.

[17] S. C. Jang, M. H. Chen, "Financial portfolio approach to optimal tourist market mixes," Tourism Management, vol. 29, no. 4, pp. 761-770, 2008.

[18] A. Barua, P. Konana, A. B. Whinston, F. Yin, "An empirical investigation of net-enabled business value," MIS quarterly, vol. 28. no. 4, pp. 585-620, 2004.
[19] S. Li, B. Ragu-Nathan, T. S. Ragu-Nathan, S. S. Rao, "The impact of supply chain management practices on competitive advantage and organizational performance," Omega, vol. 34, no. 2, pp. 107-124, 2006.

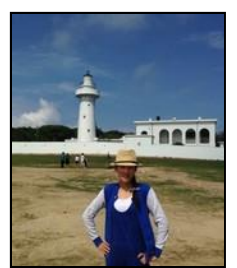

B. Y. Lee is a freelance business consultant mainly focus on New Market Entry and Long-Term Strategy for SME. He has a Master of Management Science. He has published a number of papers in various refereed journal and conference proceedings. 